\title{
PROTECTION OF EXTRAPATRIMONIAL RIGHTS IN THE NEW CIVIL CODE
}

\author{
V. Chiper (Mihalcea)
}

\section{Valentina Chiper (Mihalcea)*}

Faculty of Law and Administrative Sciences

University of Craiova, Romania

*Correspondence: Valentina Chiper (Mihalcea), University of Craiova, 13 Al. I. Cuza Street, Craiova, 200585, Dolj, Romania

E-mail:av_mihalcea@yahoo.com

\begin{abstract}
The New Romanian Civil Code, entered into force on 1 October 200, adopted by Law No. 287/2009 and implemented by Law No. 71/2011 integrates the personality rights in to non-patrimonial rights. Considering that personality rights cannot be confused with personal rights and does not integrate the heritage of the person, shall be assessed better their naming extrapatrimonial rights.

The measures which may be ordered by the Court for the protection of these rights consists either in the prohibition of unlawful deed, whether it is imminent, or cessation of the infringement and the prohibition for the future if it lasts still or finding illicit character of the committed offence, if disturbing that produced it subsists. The exception to the rule is given in cases of infringement of the rights of non-patrimonial rights by exercising the right to free speech, according to which the Court cannot order banning of illicit acts.

In the first part of the article we present a brief analysis of personality rights, and in the second part we present the analysis of extrapatrimonial rights (non-patrimonial rights) defenses.
\end{abstract}

Keywords: extrapatrimonial rights (non-patrimonial rights), personality rights, freedom of expression, protection of extrapatrimonial rights (non-patrimonial rights).

\section{Introduction}

In the New Romanian Civil Code ${ }^{1}$, Chapter II - "Respect of the Person and of His/her Innate Rights”, Title II „,The Physical Person”, Tome I - "Of Persons” (articles 58-81), the concept of "personality rights" appears in the marginal title of article 58, paragraph 1: "Any person has the right to protection of the values inherent to the human being such as life, health, physical and psychological integrity, dignity, intimacy of the private life, freedom of consciousness and scientific, artistic, literary or engineering creation", and article 252 Civil Code.

It has been estimated that the general personality right is rooted in the sixth paragraph of Article 30 of the Constitution: "Freedom of expression shall not be prejudicial to the dignity, honor, privacy of a person, and to the right to one's own image". Although the content is indeterminate and ambiguous, it brings the advantage of covering "various current

\footnotetext{
*Acknowledgements: This work was supported by the strategic grant POSDRU/CPP107/DMI1.5/S/78421, Project ID 78421 (2010), co-financed by the European Social Fund - Investing in People, within the Sectorial Operational Program Human Resources Development 2007 - 2013, University of Craiova, Faculty of Law and Administrative Sciences.

${ }^{1}$ New Civil Code - Law no. 287/2009 on the New Civil Code republished in the Official Journal no. 505/201, in effect as of October $1^{\text {st }}, 2011$.
} 
or future circumstances not having been distinctly regulated; it may also include other rights and proprietary interests in the future",

Civil liability tends also to protect one's patrimony, not only one's person. Personality rights correspond to a set of innate prerogatives meant to protect the moral or psychological integrity as between individuals, which are often opposed to human rights aiming on their side to limit the powers of the State ${ }^{3}$. Such prerogatives are innate rights specific to any human being and may be qualified as subjective rights dowering with legal action. They are non-transferable rights extinguishing upon the holder's demise which cannot pass on inheritors.

Personality rights protect man's most cherished non-pecuniary values of a general moral nature such as life, dignity, honor and private life. It is impossible to make a constant and final inventory of such rights as these vary according to historical and social changes. The French literature even speaks of an "inflation of the personality rights".

Such proprietary values profit by discretion and confidentiality, whether in respect to personal communications or phone calls or to one's private life or personal data. Personality rights are extrapatrimonial due to their non-monetary nature. Although the New Romanian Civil Code classify personality rights as non-patrimonial rights, the law, considering however that personality rights cannot be mistaken for personal rights or included in one's property, appreciates personality rights as being extrapatrimonial.

Our reference literature places extrapatrimonial rights under three categories: a) rights in respect to existence and integrity (one's physical and moral integrity, the right to life, the right to health, the right to bodily integrity, the right to honor, the right to reputation, the right to human dignity); b) rights in respect to natural person's and legal person's details (the right to a name, the right to a denomination, the right to domicile, etc.); and c) rights in respect to intellectual creation, i.e. the rights arising from the literary, artistic or scientific works and from inventions.

The new theory conveying the patrimonial nature of such rights is based on the interferences between the personality rights as extrapatrimonial rights and the patrimonial rights ${ }^{6}$ following the acknowledged validity of certain conventions relating to personality rights such as the use of the image, name and even private life.

The new Chapter II "Respect of the Person and of His/Her Innate Rights", Section 3 of "Respect to Private Life and Dignity of the Person" of the Civil Code sets out and aims to protect the right to free expression ${ }^{7}$, the right to private life ${ }^{8}$, the right to dignity ${ }^{9}$ and the

\footnotetext{
2 Ovidiu Ungureanu, Dreptul la onoare şi dreptul la demnitate, "Acta Universitatis Lucian Blaga", Iurisprudentia Series, Supplement 2005, p. 20.

${ }^{3}$ Bernard Beignier, Bertrand de Lamy, Emmanuel Dreyer, Traité de droit de la presse et des médias, Litec, LexisNexis, Paris, 2009, p. 889.

${ }^{4}$ Xavier Pradel, Le préjudice dans le droit civil de la responsabilité, Paris, Librairie Générale de Droit et de Jurisprudence, 2004, p. 123.

${ }^{5}$ Gh. Beleiu, Drept civil român. Introducere în dreptul civil. Subiectele dreptului civil, sixth edition revised and enlarged by M. Nicolae and P. Truşcă, Şansa S.R.L. Publishing House, Bucharest, 2000, p. 90.

${ }^{6}$ Edith. Deleury, Dominique Goubau, Les droits des personnes physiques, Editions Yvon Blais, Montreal, 2002, p. 74.

Article 70 of the Civil Code: The right to free expression: (1) Any person has the right to express freely. (2) The exercise of this right shall be confined under the circumstances and within the limits specified in Article 75.

${ }^{8}$ Article 71 of the Civil Code: The right to private life: (1) Any person has the right to respect of his/her privacy. (2) No one can be subject to invasions of his/her private, personal or family life at his/her domicile or residence or in his/her correspondence, without the consent of or the compliance with the limitations specified in article 75. (3) The use by any means of the correspondence, manuscripts or other personal documents and of one's private information without his/her consent or without the compliance with the limitations specified in Article 75 is also forbidden.
} 
right to one's own image ${ }^{10}$. We cannot but highlight the constitutional value the regulator bestows upon certain rights and freedoms classified as fundamental, probably in an attempt to overcome the normal constitutional rights and freedoms.

Defense of the extrapatrimonial ("non-patrimonial") rights, the new institution introduced in the new Civil Code, Chapter VI "Cancellation of the legal person", Section 3 "Special Dispositions", articles 252-257, stating that the natural person may obtain in court the protection of his/her non-patrimonial rights whenever they are breached or in case of threatened breach. The defense of the non-patrimonial rights of the legal person is similar to the natural person.

Before the coming into effect of the Civil Code, adopted by Law no. 287/2009 and enforced by Law no. 71/2011, the protection of non-patrimonial rights was regulated by Decree no. 31/1954 regarding the natural and legal persons in Chapter III. In accordance with article 54 "the person suffering a prejudice in his/her right to a name or to a nickname, to honor, to reputation, in his/her personal non-patrimonial right of author of a scientific, artistic or literary work or of inventor or in any other personal non-patrimonial right, may address to the court to prevent the perpetration in the future of the act prejudicing all above-mentioned rights. Moreover, the person suffering such prejudice shall ask the court to bind the perpetrator to publish the rendered decision at his/her expense and in the conditions established by the court or to take other actions in order to reinstate the prejudiced right".

In principle, the personal non-patrimonial rights were also subject to protection after the holder's demise and the prejudice caused could be compensated by non-patrimonial means - exemplary damages and only exceptionally by material patrimonial means according to Article 998-999 of the former Civil Code. This Decree was cancelled on the effective date of the new Civil Code in accordance with Article 230, subsection n) of enforcing Law no. $71 / 2011$.

Under the New Civil Code, actions that may be urged by the court to protect such rights resides either in:

a. the interdiction to commit illegal acts, if such interdiction is threatening (art. 253 par. 1(a) of the Civil Code);

This action can be entered before the start of the scene. The condition imposed for the exercise of this action, it is the existence of "imminence" in committing illicit acts.

$b$. the cessation of the breach and the interdiction in the future, if such breach continues, or the acknowledgment of the illegal nature of the action if the discomfort caused still lingers (art. 253 par. 1 (b) of the Civil Code);

"The cessation of the breach" is of a preventive nature, with the purpose of termination for the future already has reached to a governmental law. Ban for the future of non-patrimonial rights violations presupposes consumption violations, "but there is a serious and credible threat that another act of infringement will occur" ${ }^{\prime 1}$.

c. finding the illicit nature of the crime committed, if disturbing that produced it subsists (article 253 paragraph 1 letter $c$ of the Civil Code);

\footnotetext{
${ }^{9}$ Article 72 of the Civil Code: The right to dignity: (1) Any person has the right to respect of his/her dignity. (2) Any prejudice to the honor and reputation of a person without his/her consent or without the compliance with the limitations specified in Article 75 is forbidden.

${ }^{10}$ Article 73 of the Civil Code: The right to one's own image: (1) Any person has the right to own image.(2) In exercising the right to own image, the person may forbid or prevent the reproduction by any means of its physical appearance or voice or, as appropriate, the use of such reproduction. The dispositions of Article 75 shall apply.

${ }^{11}$ Marilena Uliescu, Noul Cod Civil. Studii şi comentarii, Vol. I Cartea I şi Cartea a II-a (art. 1-534), Universul Juridic Publishing House, Bucharest, 2012, p. 571.
} 
Conditions that relate to the nature of this action involve the determination of deed, in concrete and determined the circumstances of fact and products subsist. It is well known that the cessation of wrongful acts does not mean the immediate operation of restitution of the right violated or economic renovation, so disturbing produced pate still exist, possibly in different forms, in relation to the victim's personality or the nature of the deed.

d. the obligation of the author to illicit acts, at its expense, to the publication of the judgment of conviction (art. 253 paragraph 3 (a) of the Civil Code);

To restore governmental law violated, the Court may oblige the author, at its expense, to the judgment of condemner or any other necessary measures for the cessation of the infringing acts or to repair the damage caused. To be able to bring this action, it is necessary to the existence of a "judgment of conviction" so that this measure has a complementary character. Through the notion of publishing means any way to lead to the public. The main criterion, common to all the abuses of freedom of expression, in the case of media, is the publication of material constitutive element, essential for the existence of the media. This notion does not have a true definition, not even a clear and accurate pricing of or facts that constitute. Bear in mind the existence or absence of communities of interest, joining the recipients of the communication, whether it is a professional, friendly, associative array, if are a fact of publication.

$e$. the obligation of the author to any unlawful acts, necessary measures counted Court to enjoin illegal deed or to compensation for damage caused (art. 253 paragraph 3 (a), (b) the Civil Code).

The legislature does not give any indication to identify those specified or definable action that could be taken by the Court, so that the question arises whether or not violate the principle of availability, according to which the judge is bound to judge cause within the application with which it was endowed or can bind to other any other measures which it deems necessary having regard to the wording "any legislative measures considered necessary by the Court to reach the restoring the right reached".

The patrimonial remedy of the non-patrimonial prejudice is possible when the harm may be imputed to the author of the prejudicing act and the right of action is subject to the extinctive prescription.

As for defending the right to a name or to a nickname, the person may address the court to obtain either the recognition of the right to a name by the person whose name of challenged or the cessation of the illegitimate breach by the person prejudiced through the total or partial entrenchment of his/her name.

The person claiming to be prejudiced must produce credible proof that his/her nonpatrimonial rights are subject to an illicit, current or threatening act and that such act is likely to cause a prejudice difficult to repair.

In case of prejudice caused by means specific to the written or audiovisual press, the court cannot dispose the temporary cessation of the prejudicial act if the prejudice is not serious, the action is not clearly justified (it is permitted under the law or the international conventions on human rights adopted by Romania) and the measure urged by the court is not disproportionate against the prejudice caused.

Provisional actions that may be taken by the court consist either in the temporary interdiction or cessation of such breach or in taking the required steps to ensure the preservation of evidence.

Provisional measures provided in article 255 Civil Code, provide for the exercise of emergency procedures, in order to ensure the protection of the rights of non-patrimonial rights more effective and faster, to special measures iterated above that can be used the way common law procedure. 
The conditions necessary for the exercise of such provisional measures are: i) the making by the person who is adversely credible proof that his governmental notification necessary subject of illegal actions; ii) illicit action to be present or imminent and iii) the existence of the risk as the illicit action to cause damage difficult to repair.

After fulfilling these requirements, the person who is adversely affected may request the imposition of "especially" the following categories of provisional measures: banning nonpatrimonial rights violations, termination of the infringement, take the necessary measures to ensure the conservation of samples. Thus, the Court is not held exclusively and only imperative in these categories of provisional measures, you can take any kind of provisional measures, in compliance with the conditions provided for in article 255 of the Civil Code.

In case of prejudice caused by means specific to the written or audiovisual press, the court cannot dispose the temporary cessation of the prejudicial act if the prejudice is not serious, the action is not clearly justified (it is permitted under the law or the international conventions on human rights adopted by Romania) and the measure urged by the court is not disproportionate against the prejudice caused.

These actions are settled according to the dispositions concerning the presidential ordinance. If the request is filed before the initiation of the action on the merits, the decision stipulating the temporary measure shall also set the deadline for the initiation of the action on the merits, subject to the legal cessation of such measure. Moreover, the claimant may be forced by the curt to pay a caution if measures taken are likely to prejudice the opposite party.

Measures disposed by presidential ordinance are binding from its pronouncement, although temporary, and may cease only after the action on the merits is filed within the deadline agreed by the court or if they are continued as a result of the action on the merits (if admitted). If the action on the merits is dismissed as ungrounded, the claimant must repair the prejudice caused at the request of the interested party through the temporary measures taken. However, if the claimant is not in breach or is guilty of a minor breach, the court, in the light of actual facts, may either refuse to bind him/her to cover the claims of the opponent or to ask for their reduction.

In demise of the holder of the non-patrimonial right, the action for reinstatement of the breached non-patrimonial right may be continued or initiated after the death of the prejudiced person by the surviving spouse, by any of direct relatives of the deceased and by any of the kindred up to the forth degree. The same may file the action to reinstate the integrity of the deceased's memory.

In France, legal seizure is by its seriousness an exceptional measure that the judge, whether or not on the merits of the case or under special proceedings, shall only dictate in case of emergency if the harm to one's private life appears to be "intolerable and causing a prejudice that the subsequent compensation granted by the trial judge cannot cover"12.

The French Press Law of 1881 stipulated only the authority to seize four copies of the challenged publication in order to preserve the evidence, without considering such measure as a punishment (article 51), while the option for the civil liability under the common law, specified in Article 9, provides much more protection to privacy through prevention or stopping of the invasions of privacy and the large panel of measures available to the judge, such as the order of publication seizure or foreclosure, the order to remove or mask certain portions of the text, to insert corrections, to bind the parties to destroy books not rectified, to reverse numbers or to publish the decision at the respondent's expense.

As a measure established in the council chamber, in case of prejudice to one's honor or reputation, the person in question may address the courts either by following the

\footnotetext{
${ }^{12}$ TGI Paris, référé du 21.02.1970, JCP, 1970, II, 16293; TGI Paris, référé du 18 janvier 1996, „Affaire du Grand Secret", seizure of the book published by the personal physician of François Mitterrand, Légipresse no 128, 1996, III, 15.
} 
proceedings specified in Articles 808 and 809 of the French Code of Civil Procedure regarding the temporary ordinance or on the grounds of the dispositions in Article 9 of the Civil Code.

Such provisional measures are consistent with the dispositions of the European convention for Human Rights as asserted in the very practice of the Strasbourg Court in Leander versus Sweden on March 26, 1997 whereby such limitations are authorized by law, as well as by legislative rules, with the view to protect the reputation or the rights of the other, provided such rules are available to the predictable person of interest.

\section{Conclusions}

The rules governing institution extrapatrimonial rights are not in majority norms of the substantial law, related to the specificities of the Civil Code, but also procedural norms characteristics to the Civil Procedure Code, as found in article 253-257, concerning the procedure to protect the extrapatrimonial rights.

On the other side, many of the legal provisions, such as article 252 Civil Code, relative to article 58 paragraph 1 of the Civil Code concerning the values of "intrinsic human being, such as life, health, physical and mental integrity, dignity (...)" seem rather normative constructions of constitutional law, through which I regulates the production of other rules.

Therefore, in consideration of all these new changes made in the extrapatrimonial rights protection without a history of judicial practice and doctrine, will lead the courts dealing with a terrible battle in the interpretation and proper application and probably, often fragmented as to any beginning, the proportionality principle, endorsed and required by the European Court for Human Rights in its large practice and guidance.

\section{Bibliography}

Marilena Uliescu, Noul Cod Civil. Studii şi comentarii, Vol. I Cartea I şi Cartea a II-a (art. 1-534), Universul Juridic Publishing House, Bucharest, 2012, p. 571;

Bernard Beignier, Bertrand de Lamy, Emmanuel Dreyer, Traité de droit de la presse et des médias, Litec, LexisNexis, Paris, 2009, p. 889;

Ovidiu Ungureanu, Dreptul la onoare si dreptul la demnitate, "Acta Universitatis Lucian Blaga", Iurisprudentia, Supplement 2005, p. 20;

Xavier Pradel, Le préjudice dans le droit civil de la responsabilité, Paris, Librairie Générale de Droit et de Jurisprudence, 2004, p. 123;

Edith Deleury, Dominique Goubau, Les droits des personnes physiques, Editions Yvon Blais, Montreal, 2002, p. 74;

Gh. Beleiu, Drept civil român. Introducere în dreptul civil. Subiectele dreptului civil, sixth edition revised and enlarged by M. Nicolae and P. Truşcă, Şansa S.R.L. Publishing House, Bucharest, 2000, p. 90;

TGI Paris, référé du 21.02.1970, JCP, 1970, II, 16293; TGI Paris, référé du 18 janvier

1996, "Affaire du Grand Secret", Légipresse no 128, 1996, III, 15. 